\title{
Migration to online pharmacy education in Namibia: Successes, challenges and competence implications
}

Dan Kibuule (D), Jennie Lates (D), Anthony Ishola (D), Ester Hango, Francis Kalemeera, Michael Knott (D), Daniel Mavu (D), Bonifasius Singu (D), Timothy Rennie (D), Irene Brinkmann, Mwangana Mubita (D) University of Namibia, Namibia

\author{
Keywords \\ Challenges \\ E-learning \\ Namibia \\ Pharmacy Education \\ Correspondence \\ Dr Dan Kibuule \\ Department of Practice and Policy \\ School of Pharmacy \\ University of Namibia \\ 340 Mandume Ndemufayo Ave \\ Pionierspark \\ Windhoek \\ Namibia \\ dkibuule@unam.na
}

\begin{abstract}
Background: COVID-19, a global pandemic, has disrupted pharmacy education in Africa, due to unpreparedness to migrate to online Learning. Aim: To assess outcomes and challenges facing migration to online pharmacy education. Methods: An evaluation of implementation of online learning in the Bachelor of Pharmacy programme in Namibia using key informant feedback. The outcomes were outputs and challenges facing migration to online learning, and its impact on pass rates and scores. Results: The pooled mean score was higher in 2020 (66.2\%), compared to 2019 (63.4\%) and 2018 $(62.1 \%),(p=0.076)$. A variety of platforms were used as alternatives or supplements to Moodle. The main challenges included inequalities in internet connectivity, monitoring and quality assurance, implementation of experiential learning, and reliability of online assessment. Conclusions: Whilst migration to online learning did not impact on pass rates, there is need for policies and systems to address programmatic challenges to eliminate inequalities in online pharmacy education.
\end{abstract}

\section{Introduction}

Globally, the COVID-19 pandemic has disrupted pharmacy education to various degrees, with resource limited countries in sub-Saharan Africa the most affected (Ferrel \& Ryan 2020; Gilbert et al., 2020; Nuwagira \& Muzoora 2020). This is a concern, given the limited pharmaceutical workforce and weak pharmaceutical systems in resourcelimited settings may impact on healthcare delivery (Meghana et al., 2020; Okereke et al., 2020). Due to limited resources, most pharmacy training programmes in sub-Saharan Africa rely on traditional didactic methods and seldom integrate ICT in delivery of teaching and learning (Tran et al., 2003; Murphy, 2020). Thus, migration to online learning in pharmacy education has been implemented to varying extents in sub-Saharan Africa during the pandemic, with some institutions suspending academic activities until 2021, while others modified training to integrate online remote learning using various platforms (Mashiyane, Bangani, \& Van Deventer 2020; Mulla et al., 2020). This undermines efforts to up skill pharmaceutical workforce and strengthen pharmaceutical systems in these countries. In Namibia, during the middle 
of semester 1 in March 2020, a COVID-19-related state of emergency lockdown was imposed upon the whole country, prohibiting physical access to all education institutions including the University of Namibia (UNAM). At the same time, UNAM through its contingency plan migrated all the teaching and learning across all programmes to online platforms, mainly Moodle (Wicaksana, 2020). Moodle is a learning management system (LMS) that the University has implemented since 2015 in preparation to roll out an education aligned to the fourth industrial revolution, that is majorly studentcentred and integrates ICT in teaching and learning (Indrayana \& Sadikin, 2020). Thus, the School of Pharmacy (SoP) migrated the teaching and learning of the Bachelor of Pharmacy to online modes. The Master of Clinical Pharmacy and the Diploma in Pharmacy, both of which are work integrated programmes, had adopted a remote online learning approach earlier. Indeed, this was a major paradigm shift, to deliver pharmaceutical sciences, experiential learning and pharmacy modules via online platforms (Almaiah, Al-Khasawneh, \& Althunibat 2020). Lecturers were afforded limited time to train and migrate all teaching to online platforms under strict timelines. Fortunately, prior to the COVID-19 pandemic, the SoP had conducted capacity training twice to up-skill lecturers in online LMS, Moodle, as well as the video capture and sharing platform, Panopto (Prince \& Prince 2016; Wicaksana 2020). However, despite this training, for most staff in the School, the lockdown period was the first time that they actually carried out online teaching, so there were still setbacks with the move to online teaching. In addition, there were concerns regarding the effectiveness of migration of online pharmacy teaching and learning on attainment of intended curriculum competence outcomes of pharmacist graduates and pass rates (George et al., 2014; Coyne et al., 2019).

Consequently, this study aims to assess the successes and challenges facing migration of pharmacy education in Namibia to online teaching and learning in order to guide future curriculum review and development.

\section{Methods}

\section{Design and population}

A cross-sectional descriptive evaluation of successes and challenges facing the migration to online pharmacy education in Namibia. Qualitative data on successes and challenges of implementation of online learning, teaching and assessments were obtained through key informant (KI) interviews using a semi-structured questionnaire. The
KIs were Heads of Departments for five divisions, Pharmaceutics, Pharmacy Practice and Policy, Pharmacology and Therapeutics, Pharmacy and Pharmaceutical Chemistry and Phytochemistry, as well as the Clinical Instructor for the School of Pharmacy. An online Google survey was used to collect data from the pharmacy students regarding access to online teaching materials and challenges faced.

The secondary outcome measure was the impact of the migration to online learning on module pass rates and mean scores in 2020 compared to the preceding years (2019 and 2018) where e-learning was marginally implemented. Semester 1 examination board reports for 2020, 2019 and 2018 were used to extract data on module pass rates and mean scores and compared using Analysis of Variance (ANOVA).

\section{Procedure}

Data on challenges of online pharmacy education were collected in two phases; first through an online student survey (Table II) and then through KI feedback (Table III) from the Management of School of Pharmacy, based on feedback from staff members in their respective departments. The student survey was conducted among Bachelor of Pharmacy students through an online Google platform after two weeks of online teaching implementation. It assessed the level of access to different modules and teaching materials on Moodle as well as challenges the students experienced regarding online learning. The class representatives facilitated the data collection process from 15th to 28th April, 2020. Data from the Kls were collected using a semi-structured interview questionnaire on the challenges and successes regarding migration to online learning in July 2020, the end of the first semester. The questionnaires were administered through email and a consensus meeting was subsequently held to agree on the overarching themes regarding challenges and successes of online learning across the respective departments.

\section{Data analysis}

Qualitative data from Kls and students were thematically analysed to report themes on success and challenges facing migration to online pharmacy education in Namibia. Thematic analysis was manually conducted using colour coding and induction. The themes were independently developed by three researchers (DK, JL and MM). Tesch's eight step approach for thematic analysis was used to ensure quality assurance in the development of the themes on successes and challenges faced during 
migration to online pharmacy education in Namibia (Tesch 2013). A consensus meeting among the three researchers was subsequently held to appraise the themes. Where there were differences in opinions regarding the categorisation of a theme, a third party, i.e. the respective Head of Department, was consulted. After the development of the themes, another consultation meeting with all Heads of Departments was held to gain concurrence on the themes.

Quantitative data on semester module pass rates and module scores were compared across three years using
ANOVA in SPSS v.25 software. The level of significance for a set at 0.05 at a $95 \% \mathrm{Cl}$.

\section{Ethics}

The study is an audit of the implementation of online pharmacy education during the COVID-19 pandemic, and approval was obtained from the School of Pharmacy Research and Ethics Committee as a programme audit. The study utilised secondary data from student and lecturer feedback reports regarding the challenges and implementation of online pharmacy education, as well as

\section{Table I: Successes related to migration to online pharmacy education in Namibia}

\begin{tabular}{|c|c|c|}
\hline Theme & Sub-themes & Quotes \\
\hline \multirow[t]{9}{*}{$\begin{array}{l}\text { Innovative online } \\
\text { teaching methods }\end{array}$} & \multirow[t]{2}{*}{$\begin{array}{l}\text { Online debate duels and } \\
\text { interactive teaching }\end{array}$} & $\begin{array}{l}\text { Duels entailed two students were given an assignment to debate a pharmacy practice topic online. Record it and } \\
\text { then upload the session onto the Moodle platform for the lecturer to grade' KI Pharmacy Practice \& Policy }\end{array}$ \\
\hline & & $\begin{array}{l}\text { 'Interactive teaching in pharmaceutical sciences: using podcasting, webinars, and online learning management } \\
\text { systems like Moodle' KI Pharmaceutical Chemistry \& Phytochemistry }\end{array}$ \\
\hline & $\begin{array}{l}\text { Online simulations of } \\
\text { practical training }\end{array}$ & $\begin{array}{l}\text { MyDispense software for practical training: a virtual teaching and learning method that has been employed prior } \\
\text { and during COVID-19 state of emergency to train on pharmacy practice skills on dispensing and medication } \\
\text { counseling. This has been adapted to training on medicines commonly used in the Namibian setting. This is provided } \\
\text { through an independent platform supported by Monash University.' KI Pharmacy Practice \& Policy }\end{array}$ \\
\hline & $\begin{array}{l}\text { Online Case-based } \\
\text { learning approach for } \\
\text { clinical instruction }\end{array}$ & $\begin{array}{l}\text { Clinical instructors collect and write up actual patient cases by documenting only the subjective and objective } \\
\text { patient information. Students then prepare pharmaceutical care plans for each case provided by completing the } \\
\text { assessment and plans. This is supplemented with online teaching tutorials and case-based discussions using Zoom } \\
\text { and Google Meet'. KI Clinical Instructor }\end{array}$ \\
\hline & \multirow[t]{2}{*}{$\begin{array}{l}\text { Alternative Modes of } \\
\text { online delivery of } \\
\text { teaching and learning }\end{array}$} & $\begin{array}{l}\text { A combination of two virtual platforms were adopted mainly, Moodle platform and WhatsApp. The WhatsApp is } \\
\text { inexpensive relative to Moodle to effective share of teaching resources and notes to the students. KI Pharmacology } \\
\text { and Therapeutics }\end{array}$ \\
\hline & & $\begin{array}{l}\text { 'Teaching Mathematics remotely was a challenge, as this is one of the subjects first year students struggle with. The } \\
\text { lecturer overcame this by using a combination of Panopto videos shared on Moodle, a dedicated class WhatsApp } \\
\text { group, and frequent mini quizzes to check students grasp of concepts taught.' KI Pharmacy }\end{array}$ \\
\hline & $\begin{array}{l}\text { Practical teaching in } \\
\text { basic sciences using } \\
\text { video demonstrations }\end{array}$ & $\begin{array}{l}\text { Video demonstration of practicals: This included use of recorded videos to demonstrate practical sessions in } \\
\text { pharmaceutical chemistry-such as A is for Aspirin published by Rennie et al 2019. This was accompanied by a write } \\
\text { up of report and an online assessment of the understanding of critical skills'. KI Pharmaceutical Chemistry \& } \\
\text { Phytochemistry }\end{array}$ \\
\hline & \multirow[t]{2}{*}{$\begin{array}{l}\text { Enhanced contextual } \\
\text { and reflective training: }\end{array}$} & $\begin{array}{l}\text { The theoretical online perspective of pharmaceutical chemistry was contextualized to align with key competences } \\
\text { required to address priority health related problems in Namibia such as chemistry of medicines used to treat } \\
\text { malaria, HIV/AIDS and TB. This certainly gives the students a very good background of pharmacy in the Namibian } \\
\text { context. KI Pharmaceutical Chemistry \& Phytochemistry }\end{array}$ \\
\hline & & $\begin{array}{l}\text { 'Reflective learning: during the remote online learning, students were encouraged to reflect on the challenges } \\
\text { regarding learning and application of concepts. Students completed reflection logs to facilitate reflective learning } \\
\text { practices'. KI Pharmaceutical Chemistry \& Phytochemistry }\end{array}$ \\
\hline \multirow{5}{*}{$\begin{array}{l}\text { Administration } \\
\text { and development } \\
\text { of online content } \\
\text { and resources }\end{array}$} & \multirow{3}{*}{ Voice over lecturers } & $\begin{array}{l}\text { Summary voice over lectures: lecture material per session were uploaded on Moodle accompanied with a short } \\
\text { summary video emphasizing key learning messages and contents'. KI Pharmacy Practice \& Policy }\end{array}$ \\
\hline & & $\begin{array}{l}\text { 'Transition of delivery of clinical rotations to Moodle platform: learning resources such as review articles, clinical } \\
\text { practice guidelines and videos are uploaded to Moodle'. KI Pharmacy Practice \& Policy }\end{array}$ \\
\hline & & $\begin{array}{l}\text { 'Archive of clinical cases: clinical instructors also make use of actual patient cases that were written up students in } \\
\text { the past'. KI Clinical instructor }\end{array}$ \\
\hline & \multirow[t]{2}{*}{ Online administration: } & $\begin{array}{l}\text { The success of online teaching of pharmacology leaned on perfect coordination - that is, uploading of teaching } \\
\text { material, and timeously communicating with the students regarding the materials and assessments.' KI } \\
\text { Pharmacology and Therapeutics }\end{array}$ \\
\hline & & $\begin{array}{l}\text { 'Cost-saving: online learning enabled the department to teach pharmacology for nursing students at four campuses, } \\
\text { thus sparing the costs for travel, accommodation and subsistence associated with face-to-face lectures at the three } \\
\text { campuses excluding main campus.' KI Pharmacology and Therapeutics }\end{array}$ \\
\hline \multirow[t]{2}{*}{$\begin{array}{l}\text { Enhanced quality } \\
\text { of online } \\
\text { assessments }\end{array}$} & \multirow[t]{2}{*}{$\begin{array}{l}\text { Innovations with regards } \\
\text { to online formative } \\
\text { assessments }\end{array}$} & $\begin{array}{l}\text { To ensure reliability and validity of the assessments and to minimize plagiarism. Essay questions were emailed or } \\
\text { posted on Moodle one at a time for a fixed time period. Students were expected to immediately post answers to } \\
\text { lecturer within the } 5 \text { minutes at the end of the time period through WhatsApp or Moodle. Possibilities of plagiarism } \\
\text { was minimized by this approach'. KI Pharmaceutical Chemistry \& Phytochemistry }\end{array}$ \\
\hline & & $\begin{array}{l}\text { 'In the absence of viva voce examination, an end of semester objective structured clinical examination (OSCE) will be } \\
\text { completed. A combination of a viva voce and OSCE would ideally comprehensively assess students' knowledge, } \\
\text { attitudes and skills if the situation allows'. KI Clinical Instructor }\end{array}$ \\
\hline
\end{tabular}


reports on module scores. The study did not capture student and $\mathrm{KI}$ specific identifiers and records were confidentially stored and protected

\section{Results}

The response rate among the key informants was $100 \%$ ( $n=6 / 6)$, and 95\% in the student survey $(n=180 / 190)$.

\section{Successes of migration to online pharmacy education}

The first success the School achieved was that 98\% $(177 / 180)$ of students could access all their modules on Moodle within a month of moving to online learning. Without students being able to access this platform, the School would have failed at the first hurdle. Table I highlights the key innovations in implementing online pharmacy education in Namibia. All five departments in the School used Moodle, the University preferred online LMS, to deliver learning, teaching and assessments. However, the extent of integration and utility of Moodle varied across and within departments, depending on the level of prior knowledge and confidence using the platform. The main successes pertained to innovations to improvise other online platforms to supplement, or as an alternative to, teaching and learning using the Moodle platform. The alternative platforms used included social media such as WhatsApp and interactive conferencing platforms such as Zoom and Google Meet. These innovations enhanced live interaction with the learners and ensured the reliability and validity of assessments, as well as increased access to cost-effective online learning and teaching (Table I).

Experiential and practical learning and training were successfully modified; clinical training required the clinical instructor to collect data on a real patient case, upload the case on Moodle for students to complete pharmaceutical care plans, which were then discussed during a live online session. The laboratory practical sessions were modified such that the responsible lecturer and/or technician video recorded the experiment with a narrative and students completed a report of the experiment. After this, discussions on the experiment were completed through an online class. In addition, students completed practical activities in pharmacology and pharmacy practice by use of online simulation software.

The final success recorded was that the semester module pass rates and average marks appeared to be higher in Semester 1, 2020 (implementation of online learning) compared to Semester 1 of previous years, and students were directly and actively involved in their learning.

\section{Challenges faced during migration to online pharmacy education}

Key informants and students' responses to the survey, highlighted several challenges pertaining to migration to online pharmacy education.

The student related challenges include: inequalities in internet connectivity particularly among students in remote settings or from disadvantaged backgrounds, lack of equipment such as laptops to access online learning, increase in the workload for students due to overload with assignments, noncompliance of lecturers to their time schedules and limited feedback from module leads (Table Ilc).

Table II (a, b, c): Challenges faced by students with migration to online learning

Table II (a): Responses by year of study

\begin{tabular}{lccc}
\hline Year & Count & Class size & \% response \\
\hline BPharm 1 & 42 & 45 & 93 \\
BPharm 2 & 55 & 55 & 100 \\
BPharm 3 & 40 & 41 & 98 \\
BPharm 4 & 43 & 49 & 88 \\
Total & $\mathbf{1 8 0}$ & $\mathbf{1 9 0}$ & $\mathbf{9 5}$ \\
\hline
\end{tabular}

Table II (b): Access to Moodle

\begin{tabular}{lcc}
\hline Access to Moodle & Count & $\%$ \\
\hline I cannot access Moodle at all & 0 & 0 \\
I can access Moodle, but cannot access all my modules & 3 & 2 \\
I can sometimes access Moodle, but not all the time & 52 & 29 \\
Yes - I can access all my modules & 125 & 69 \\
Total & $\mathbf{1 8 0}$ & $\mathbf{1 0 0}$ \\
\hline
\end{tabular}

*All three students contacted, assisted and were able to access resources for all modules by 28 April 2020

** Reasons provided by those who responded that they can access Moodle, but not all the time are included in Table II c.

The KIs highlighted the following challenges; Moodle lacks several features for effective delivery of online pharmacy learning, limited learning support and interactions with students during remote learning, monitoring and quality assurance of teaching, learning and assessments, implementation of experiential, practical and clinical learning, reliability and validity of online assessment, lack of comprehensive policies to guide the online learning, teaching and assessment processes, inflexibility in implementing elearning and increase in workload to develop online teaching content and assessments (Table III). 
Table II (c): Challenges faced and suggestions made by students

\begin{tabular}{|c|c|c|}
\hline Theme & Sub-themes & Details and Quotes \\
\hline \multirow[t]{2}{*}{$\begin{array}{l}\text { Internet access and } \\
\text { connectivity }\end{array}$} & $\begin{array}{l}\text { Access to modules } \\
\text { on the Moodle LMS }\end{array}$ & $\begin{array}{l}\text { Students access to modules on Moodle: Although only } 2 \%(n=3) \text { of students could not access their modules on } \\
\text { Moodle initially, almost a third of students }(n=52,29 \%) \text { could not access their modules all the time. The reasons } \\
\text { provided for this were as follows; general poor internet }(n=34) \text {; poor TN Mobile* connection }(n=7) \text {; no TN Mobile* } \\
\text { connection ( } n=4) \text { and other }(n=13) \text {, including lack of reliable device to access Moodle, no power at home to charge } \\
\text { laptop, childcare duties, if too many students on Moodle at same time page / app does not open. }\end{array}$ \\
\hline & $\begin{array}{l}\text { Mobile network } \\
\text { challenges: }\end{array}$ & $\begin{array}{l}\text { Mobile network challenges included; general Poor internet ( } n=34) \text {; poor TN Mobile* connection }(n=7) \text {; no TN Mobile* } \\
\text { connection }(n=4) \text {. Several students only succeed to access Moodle or upload assignments when they use MTC* data, } \\
\text { that they had to pay for or by visiting relatives' workplaces to access internet. }\end{array}$ \\
\hline \multirow[t]{2}{*}{$\begin{array}{l}\text { Student suggestions } \\
\text { to improve online } \\
\text { pharmacy } \\
\text { education }\end{array}$} & $\begin{array}{l}\text { Improve } \\
\text { completion of } \\
\text { learning activities } \\
\text { and assessments }\end{array}$ & $\begin{array}{l}\text { The suggestions made included the following; allow assessments / quizzes to be open for longer so that students with } \\
\text { poor internet access have chance to complete quiz, lecturers to be lenient re students not meeting due dates, open } \\
\text { the library so that students can access books, lecturers should do audio / video files to accompany their slides, as } \\
\text { slides alone are not clearly understood, lecturers should make sure that their Panopto videos can be downloaded, } \\
\text { students should be notified by email whenever the lecturer posts something on Moodle. }\end{array}$ \\
\hline & $\begin{array}{l}\text { Access to } \\
\text { downloadable } \\
\text { teaching resources }\end{array}$ & $\begin{array}{l}\text { Downloadable voice overs: as a direct result of the survey students who had problems accessing their modules or } \\
\text { lacking TN Mobile devices were assisted; the School management set guidelines for quiz availability and encouraged } \\
\text { lecturers to do voice-over and or Panopto videos and informed that Panopto videos should be set up so that students } \\
\text { can download and watch offline }\end{array}$ \\
\hline
\end{tabular}

*UNAM provides each student with a TN mobile device and 5GB free data/month, to enable students to access the internet. However the TN mobile service is not reliable in some areas and non-existent in very rural areas. MTC internet connection is much wider spread, but then students have to pay for the data they use.

Table III: Key Informants challenges faced with migration to online learning, teaching \& assessments

\begin{tabular}{|c|c|c|}
\hline Theme & Sub-themes & Quotes \\
\hline \multirow[t]{6}{*}{$\begin{array}{l}\text { Limited hands-on } \\
\text { training }\end{array}$} & \multirow[t]{2}{*}{$\begin{array}{l}\text { Limited access to } \\
\text { practical reference } \\
\text { resources }\end{array}$} & $\begin{array}{l}\text { Pharmacy practice training requires access to information from limited literature resources that are only available in } \\
\text { hard copy in the practical venue (Mock Pharmacy) at the UNAM School of Pharmacy such as the British Pharmacopoeia } \\
\text { (BP) and Medicine formularies.' KI Pharmacy Practice \& Policy }\end{array}$ \\
\hline & & $\begin{array}{l}\text { 'Consequently, all practical activities were transformed into assignments that did not require the students to consult } \\
\text { from these books, this disadvantaged the students as they could not learn the intended practical skill of sourcing } \\
\text { medicines information from reputable sources.' KI Pharmacy Practice \& Policy }\end{array}$ \\
\hline & \multirow[t]{3}{*}{$\begin{array}{l}\text { Limited experiential } \\
\text { clinical instructions }\end{array}$} & $\begin{array}{l}\text { Experiential clinical training: the inability to undertake real time clinical instruction in the clinical environment. This } \\
\text { challenge has various ramifications such as loss of a multidisciplinary environment, which is a requisite for } \\
\text { inter-professional education and practice.' KI Pharmacy Practice \& Policy }\end{array}$ \\
\hline & & $\begin{array}{l}\text { 'Limited 'hands-on' experience acquired through collection of clinical information by reviewing clinical records of actual } \\
\text { patients' KI Clinical instructor }\end{array}$ \\
\hline & & $\begin{array}{l}\text { 'Limited laboratory experiential skills: students had limited exposure or training in the laboratory during online } \\
\text { learning.' KI Pharmaceutical Chemistry \& Phytochemistry }\end{array}$ \\
\hline & \begin{tabular}{|l|} 
Incomplete \\
learning experience
\end{tabular} & $\begin{array}{l}\text { In terms of Pharmaceutical Science teaching, the theory is fully integrated with both the chemistry practicals and } \\
\text { work-based pharmaceutical experiences in the community (and vice versa). This ensures that theory and practice are } \\
\text { sensibly linked together in a manner which will fulfil the student and lecturer learning experience.' KI Pharmaceutical } \\
\text { Chemistry \& Phytochemistry }\end{array}$ \\
\hline $\begin{array}{l}\text { Reduced module } \\
\text { completion rates }\end{array}$ & $\begin{array}{l}\text { Student dropout } \\
\text { and loss to } \\
\text { follow-up }\end{array}$ & $\begin{array}{l}\text { For Biopharmaceutics and Pharmacokinetics, } 89 \% \text { successfully completed the module. A total of } 54 \text { BPharm III students } \\
\text { took systems pharmacology II, of which } 89 \% \text { successfully completed the module. For this same year, } 42 \text { took } \\
\text { chemotherapy, of which } 93 \% \text { successfully completed the module. KI Pharmacology and Therapeutics }\end{array}$ \\
\hline \multirow[t]{3}{*}{$\begin{array}{l}\text { ICT infrastructure } \\
\text { inequalities }\end{array}$} & \multirow[t]{2}{*}{$\begin{array}{l}\text { Poor internet } \\
\text { connectivity }\end{array}$} & $\begin{array}{l}\text { Of the } 2.9 \% \text { BSCN and } 3.8 \% \text { of MBChB who did not complete the module. Some of those who did not complete the } \\
\text { module } 1.2 \%(n=4) \text { seemed to have had limited online connectivity.' KI Pharmacology and Therapeutics }\end{array}$ \\
\hline & & $\begin{array}{l}\text { Internet connection was present most of the time in Windhoek but the connection speed, especially in the first two } \\
\text { months of online teaching, was terrible, making it impossible to reasonably expect students to complete a Moodle quiz } \\
\text { with } 2 \text { minutes per MCQ, as each page on Moodle took at least } 2 \text { minutes to load at certain times of the day' KI } \\
\text { Pharmacy }\end{array}$ \\
\hline & $\begin{array}{l}\text { High connectivity } \\
\text { costs }\end{array}$ & $\begin{array}{l}\text { "Limited the range and scope of teaching and learning experiences by the staff and students." KI Pharmaceutical } \\
\text { Chemistry \& Phytochemistry }\end{array}$ \\
\hline \multirow[t]{4}{*}{$\begin{array}{l}\text { Quality assurance } \\
\text { issues }\end{array}$} & \multirow[t]{2}{*}{$\begin{array}{l}\text { High workload on } \\
\text { staff members }\end{array}$} & $\begin{array}{l}\text { "Increased workload and level of effort: the level-of-effort increased in the preparing of videos, but this will be } \\
\text { associated with lower level-of-effort in the future. KI Pharmacology and Therapeutics }\end{array}$ \\
\hline & & $\begin{array}{l}\text { "Online teaching required repackaging of lecture materials in pharmaceutical sciences on online delivery who had } \\
\text { limited literacy on use of learning management systems such as Moodle." KI Pharmaceutical Chemistry \& } \\
\text { Phytochemistry }\end{array}$ \\
\hline & $\begin{array}{l}\text { Reliability and } \\
\text { validity of online } \\
\text { assessments }\end{array}$ & $\begin{array}{l}\text { "Reliability of online assessment: One of the challenges we experienced was reformatting the types of chemistry related } \\
\text { questions we could ask online. For example, it is difficult to draw a mechanism of action if you are limited to online } \\
\text { MCQ type questions." KI Pharmaceutical Chemistry \& Phytochemistry } \\
\text { "Online tests have flaws, for example, students can quickly 'google' the answer without your knowledge. It is also } \\
\text { difficult to assess a student's practical skills without observing them in practice." KI Pharmaceutical Chemistry \& } \\
\text { Phytochemistry }\end{array}$ \\
\hline & \begin{tabular}{|l|} 
Reduced \\
interactive learning
\end{tabular} & $\begin{array}{l}\text { "There was reduced interactive participating in online learning by students and staff members and impacts on } \\
\text { acquisition of soft skills such as communication and leadership skills." KI Pharmaceutics }\end{array}$ \\
\hline
\end{tabular}




\section{Impact of migration to online pharmacy education on module pass rates and scores}

The pooled mean score across the semester 1 modules was highest in 2020 (66.2\%) compared to 2019 (63.4\%) and 2018 (62.1\%). Similarly, the pass rates across the modules were higher in 2020 compared to 2019 and 2018. However, an analysis of variance did not show any significant difference in the pass rates $(F=0.879, D F=2$, $p=0.421)$ and average marks ( $F=2.69, D F=2, p=0.076)$ across the years 2018, 2019 and 2020, however, the $t$-test showed a significantly higher pass rate between 2018 and 2020. Nevertheless the pooled result was significantly higher in 2020 compared to the combined 2018 and 2019 average mark ( $\mathrm{F}=0.199, \mathrm{DF}=64, p=0.030$ ) (Table IV).

Table IV: Impact of migration to online pharmacy education on module pass rates and average scores

\begin{tabular}{|c|c|c|c|c|c|c|c|}
\hline \multirow[b]{2}{*}{$\begin{array}{l}\text { Year of } \\
\text { study }\end{array}$} & \multirow[b]{2}{*}{ Module } & \multicolumn{3}{|c|}{ Average scores } & \multicolumn{3}{|c|}{ Pass rates } \\
\hline & & 2018 & 2019 & 2020 & 2018 & 2019 & 2020 \\
\hline 1 & Anatomy I & 64.1 & 69.7 & 81.5 & $90 \%$ & $95 \%$ & $100 \%$ \\
\hline 1 & Mathematics & 52.7 & 69.8 & 63.1 & $61 \%$ & $86 \%$ & $95 \%$ \\
\hline 1 & Organic Chemistry & 58.5 & 58.1 & 54.6 & $84 \%$ & $85 \%$ & $85 \%$ \\
\hline 1 & Physiology I & 53.1 & 53.4 & 57.5 & $58 \%$ & $50 \%$ & $90 \%$ \\
\hline 1 & Primary Health Care & 69.5 & 67.4 & 76.5 & $98 \%$ & $100 \%$ & $100 \%$ \\
\hline 2 & Biochemistry II & 62.2 & 58.7 & 65.0 & $100 \%$ & $92 \%$ & $94 \%$ \\
\hline 2 & $\begin{array}{l}\text { General } \\
\text { Pharmaceutics }\end{array}$ & 60.6 & 65.3 & 66.1 & $65 \%$ & $94 \%$ & $94 \%$ \\
\hline 2 & Inorganic Chemistry & 57.0 & 61.8 & 55.2 & $79 \%$ & $91 \%$ & $88 \%$ \\
\hline 2 & $\begin{array}{l}\text { Introduction to } \\
\text { Pharmacy \& } \\
\text { Dispensing }\end{array}$ & 58.4 & 61.8 & 65.4 & $85 \%$ & $87 \%$ & $98 \%$ \\
\hline 2 & Physiology III & 58.0 & 51.8 & 64.5 & $83 \%$ & $42 \%$ & $94 \%$ \\
\hline 2 & $\begin{array}{l}\text { Systems } \\
\text { Pharmacology I }\end{array}$ & 64.2 & 60.9 & 74.1 & $100 \%$ & $91 \%$ & $100 \%$ \\
\hline 3 & $\begin{array}{l}\text { Biopharmaceutics \& } \\
\text { Pharmacokinetics }\end{array}$ & 69.9 & 65.1 & 58.3 & $88 \%$ & $79 \%$ & $93 \%$ \\
\hline 3 & Chemotherapy & 66.4 & 58.1 & 69.6 & $100 \%$ & $96 \%$ & $95 \%$ \\
\hline 3 & Law and Ethics & 72.3 & 63.0 & 68.4 & $100 \%$ & $96 \%$ & $100 \%$ \\
\hline 3 & $\begin{array}{l}\text { Pharmaceutical } \\
\text { Microbiology }\end{array}$ & 58.4 & 58.0 & 65.7 & $92 \%$ & $73 \%$ & $98 \%$ \\
\hline 3 & $\begin{array}{l}\text { Pharmacognosy \& } \\
\text { Phytochemistry }\end{array}$ & 68.0 & 60.6 & 75.9 & 88 & $85 \%$ & $100 \%$ \\
\hline 3 & $\begin{array}{l}\text { Systems } \\
\text { Pharmacology II }\end{array}$ & 70.6 & 65.1 & 62.9 & $100 \%$ & $75 \%$ & $93 \%$ \\
\hline 3 & $\begin{array}{l}\text { Veterinary } \\
\text { Pharmacy \& } \\
\text { Agrochemicals }\end{array}$ & 56.0 & 55.8 & 62.3 & $78 \%$ & $78 \%$ & $96 \%$ \\
\hline 4 & $\begin{array}{l}\text { Complementary \& } \\
\text { Alternative } \\
\text { Medicine }\end{array}$ & 64.6 & 67.1 & 68.9 & $100 \%$ & $100 \%$ & $100 \%$ \\
\hline 4 & $\begin{array}{l}\text { Medicinal Chemistry } \\
\text { II }\end{array}$ & 72.4 & 64.1 & 68.2 & $100 \%$ & $88 \%$ & $100 \%$ \\
\hline 4 & $\begin{array}{l}\text { Pathophysiology \& } \\
\text { Pharmacotherapy II }\end{array}$ & 70.0 & 66.1 & 64.6 & $100 \%$ & $97 \%$ & $100 \%$ \\
\hline 4 & $\begin{array}{l}\text { Pharmaceutical } \\
\text { Technology II }\end{array}$ & 66.8 & 64.3 & 68.8 & $100 \%$ & $97 \%$ & $100 \%$ \\
\hline
\end{tabular}

\section{Discussion}

This study reports that, despite challenges, online education was successfully carried out in all pharmacy departments and modules. One clear indication of this is that the module pass rates and mean class scores were comparable to those achieved through face-to-face teaching in 2018 and 2019. Additional successes of migration to online learning were scale-up of use of ICT to deliver pharmacy education in Namibia, promotion of student-centred learning and innovations to use alternative means to promote interactive teaching and ensure reliability of assessments.

The School of Pharmacy in Namibia was uniquely placed to implement online learning relative to other schools in the African region (Mashiyane, Bangani, \& Van Deventer 2020). This is due to the ICT infrastructure being in place before the COVID-19 outbreak. UNAM, through the Centre of Open Distance and elearning (CODeL), implemented Moodle in 2015 across the whole university to support distance- and work-based programmes (Rudall, Kalemeera \& Rennie 2015; Nunes-da-Cunha \& FernandezLlimos, 2019).

Online education has been posited as having promise to enhance access to quality pharmacy education and improve pass rates, however this study highlights some major barriers that exist with regards to adaptation to online learning. These include high connectivity costs, more workload on staff members as lectures, tutorials and practicals all have to be repackaged for online delivery (Khadmlu et al., 2013; Mashiyane, Bangani, \& Van Deventer 2020; Murphy 2020). Lack of qualified, ICT-savvy academics, information technology (IT) technical support and educational design support, have the potential to distract students from actively participating and can decrease students' social skills (Muiruri et al., 2014), increase dropout rates and could result in students who are poor in face-to-face communication (Alkoudmani \& Elkalmi 2015; Julius, Nuugulu, \& Julius, 2020).

The migration to online pharmacy education exposed the risks of depending on one LMS, such as Moodle, for all learning and assessment requirements. Moodle is not comprehensive enough to deliver all components required of professional programmes, such as pharmacy, that involve hands-on experiences. Whilst Moodle was the recommended LMS, lecturers used several other platforms (e.g. Zoom, Google Meet, emailing, WhatsApp) to complement, and in some cases, as alternatives to Moodle. This was mainly due to limited knowledge and confidence in use of the recommended platform, as well 
as the limitation of the platform to deliver effective learning to achieve competences unique to the module or the pharmacy profession (Mashiyane, Bangani, \& Van Deventer 2020). For instance, it's a challenge to deliver modules such as pharmaceutical sciences that require demonstration of calculations and chemical equations using the recommended platform (Muiruri et al., 2014; Safari, Alikhani, \& Safari 2016). Furthermore, it was unlikely that one platform or method would adequately suit all modules, all lecturers and be able to deliver training on all learning outcomes in the pharmacy degree. Thus, there is a need for flexibility to allow use of a variety of platforms to tailor learning and teaching, to meet the needs of a professional course (Jeffries et al., 2013; Vovides et al., 2014). The use of several platforms resulted in the inability of senior management to monitor the effectiveness of the teaching and learning among the individual lecturers (Vovides et al., 2014).

This study identified several thematic challenges experienced with the migration to online learning, mainly pertaining to quality assurance of learning, teaching and assessments, institutional unpreparedness and staff acceptability to migrate to online learning, limited student learning support systems, inequalities in access to ICT equipment and connectivity, limited capabilities of the recommended Moodle LMS for effective online learning and teaching, and lack of institutional quality assurance guidelines specific to online education. Furthermore, there are concerns regarding implementation of experiential learning in the context of remote eLearning.

The main challenges pertaining to migration to online pharmacy education were firstly limited support during remote learning as some students and staff were isolated (Khadmlu et al., 2013). Secondly, experiential learning experiences in pharmacy can never be fully replaced with online learning, including clinical modules that required contact with patients as well as laboratory experience (Khadmlu et al., 2013; Henman, Kibuule, \& Mubita 2019).

It is important to emphasise that the criteria for effective teaching, in a changing higher education context, involves reflection and continually responding to the contexts in which learning and teaching is undertaken (Devlin \& Samarawickrema, 2010; Means et al., 2013). In Namibia, with its historically inequitable access to education, factors that affect equitable access to education are taken very seriously. The limited connectivity to internet was a major barrier to equitable access to pharmacy education. Inequalities were caused because the internet dongle, provided to all students by UNAM, did not work at all in some locations and in other locations provided such weak internet access as to be little better than useless. Some students negatively affected by this were able to afford the costs associated with buying data bundles on the alternative internet service provider, whereas students from more disadvantaged backgrounds did not have this option available to them (Elletson \& MacKinnon 2014).

The other major challenge pertained to reliability and validity of online assessments. Few lecturers had been trained on how to migrate the conventional examinations (i.e. summative assessment) to an online platform (Elletson \& MacKinnon 2014; Muiruri et al., 2014). There are concerns regarding the securing of the exams and assessments posted on online platforms as well as migration to open-book assessments that may encourage plagiarism (Khadmlu et al., 2013; Almaiah, Al-Khasawneh, \& Althunibat 2020). Quality assurance measures need to be put in place to ensure quality and validity of these open book assessments, given that assessments are the main driver of learning (Muiruri et al., 2014).

The study did not find significant differences in the pass rates and average marks, however this should be interpreted in the context of the assessments conducted. During online learning there is a risk of conducting fewer practical and clinical assessments that assess the skills of the students, and assessments were largely open-book.

\section{Limitations}

The findings of this study should be interpreted in the context of several limitations, including the study assessed only one programme, during a limited period of implementation of online learning and assessed the use of one LMS - Moodle. The study did not assess the impact of online learning on the competences of pharmacist graduates. Nevertheless, the study provides important findings on the state of implementation of online pharmacy education in a resource-limited setting in sub-Saharan Africa. This is important for pharmacy curriculum reforms in the context of the fourth industrial revolution, given that the region has the lowest pharmacy workforce index globally and generally weak pharmaceuticals systems (Bates et al., 2016).

\section{Conclusion}

The study concludes that UNAM School of Pharmacy successfully implemented online learning in undergraduate pharmacy programme, in difficult circumstances, given the nationwide lockdown enforced due to the COVID-19 pandemic. These unique circumstances in fact resulted in innovative methods being developed by 
lecturers to meet the needs of their various modules. Despite these successes, both students and lecturers faced challenges with the migration to online learning, especially related to equitable access to online resources for students and concerns related to quality assurance of learning and assessments for the lecturers.

The move to online pharmacy education did not significantly improve or reduce pass rates and performance, compared to face-to-face teaching. From the experiences reported by students and lecturers in the study the authors wish to highlight the importance of developing systems that both ensure quality and support learning, teaching and assessments whilst permitting flexibility in implementation of online learning in pharmacy education. Lecturers should be encouraged to use additional modalities to complement online learning in order to provide pharmacy education that fosters student-based leaning in a work environment. The authors recommend other studies to assess the impact of implementation of online learning on the pharmacy graduate competences.

\section{References}

Alkoudmani, R.M., \& Elkalmi, R.M. (2015). Challenges to Web-Based Learning in Pharmacy Education in Arabic Language Speaking Countries. Archives of Pharmacy Practice, 6(3). 41. https://doi.org/10.4103/2045-080X.160989

Almaiah, M.A., Al-Khasawneh, A., \& Althunibat, A. (2020). Exploring the Critical Challenges and Factors Influencing the E-Learning System Usage during COVID-19 Pandemic. Education and Information Technologies, (2020). https://doi.org/10.1007/ s10639-020-10219-y

Bates, I., John,C., Bruno, A, Fu, P., \& Aliabadi, S. (2016). An Analysis of the Global Pharmacy Workforce Capacity. Human Resources for Health, 14(1), 61. https://doi.org/10.1186/s12960-016-0158-z

Coyne, L., Merritt, T.A., Parmentier, B.L., Sharpton, R.A., \& Takemoto, J.K. (2019). The Past, Present, and Future of Virtual Reality in Pharmacy Education. American Journal of Pharmaceutical Education, 83(3), 281-90. https://doi.org/10.5688/ ajpe7456

Devlin, M., \& Samarawickrema, G. (2010). The Criteria of Effective Teaching in a Changing Higher Education Context. Higher Education Research and Development, 29(2), 111-24. https://doi. org/10.1080/07294360903244398

Elletson, H., \& MacKinnon, A. (2014). The eLearning Africa Report 2014, ICWE: Germany. Available at: www.elearning-africa.com/ report2014

Ferrel, M.N, \& Ryan, J.J. (2020). The Impact of COVID-19 on Medical Education. Cureus, 12(3), e7492. https://doi.org/10.7759/ cureus.7492
George, P.P., Papachristou, N., Belisario, J.M., Wang, W., Wark, P.A. et al., (2014). Online ELearning for Undergraduates in Health Professions: A Systematic Review of the Impact on Knowledge, Skills, Attitudes and Satisfaction. Journal of Global Health, 4(1). https://doi.org/10.7189/jogh.04.010406

Gilbert, M., Pullano, G., Pinotti, F., Valdano, E., Poletto, C., et al. (2020). Preparedness and Vulnerability of African Countries against Importations of COVID-19: A Modelling Study. The Lancet, 395(10227), 871-77. https://doi.org/10.1016/S0140-6736(20) 30411-6

Henman, M., Kibuule, D., \& Mubita, M. (2019). Teaching Pharmaceutical Care to Pharmacists and Other Health Professionals. In The Pharmacist Guide to Implementing Pharmaceutical Care, (eds. F. Alves da Costa, J. van Mil., A. Alvarez-Risco), Springer, Cham, pp.491-502. https://doi.org/10. 1007/978-3-319-92576-9 40

Indrayana, B., \& Sadikin, A. (2020). The Application of E-Learning in the Era of the Industrial Revolution 4.0 to Suppress the Spread of Covid-19. Indonesion Journal of Sport Science and Coaching, 2(1), 46-55. https://doi.org/10.22437/ijssc.v2i1.9847

Jeffries, J., Jeffries, P., Hertig, J., \& Hultgren, K. (2013). Embracing Pharmacy E-Learning: Models of Success. Pharmacy, 1(1), 43-52. https://doi.org/10.3390/pharmacy 1010043

Khadmlu, M., Alizadeh, A., Hosseini, H., Mohammadi, A., \& Fakhar, M. (2013). Health and Pharmacy Students' Views about the Use of Elearning Systems and Its Related Factors. Journal of Mazandaran University of Medical Sciences, 22(Sup. 2), 116-120

Mashiyane, D.M, Bangani, S., \& Van Deventer, K. (2020). The Awareness and Application of Multimedia Tools for Information Literacy Instruction at an African University. Electronic Library. https://doi.org/10.1108/EL-02-2020-0027

Means, B., Toyama, Y., Murphy, R., \& Baki, M. (2013). The Effectiveness of Online and Blended Learning: A Meta-Analysis of the Empirical Literature. Teachers College Record, 115(3)

Meghana, A., Aparna, Y., Chandra, S.M., \& Sanjeev, S. (2020). Emergency Preparedness and Response (EP\&R) by Pharmacy Professionals in India: Lessons from the COVID-19 Pandemic and the Way Forward. Research in Social and Administrative Pharmacy. https://doi.org/10.1016/i.sapharm.2020.04.028

Muiruri, C., Kapanda, G., Tibyampansha, D., Ibrahim, G., Kulanga, A., Lisasi, E., \& Bartlett, J. (2014). eLearning at a Medical School in sub-Saharan Africa: Use of the Technology Acceptance Model to evaluate implementation effectiveness. Annals of Global Health, 80(3), 171-172. http://doi.org/10.1016/i.aogh.2014.08.043

Mulla, Z.D., Osland-Paton, V., Rodriguez, M.A., Vazquez, E., \& Plavsic, S.K. (2020). Novel Coronavirus, Novel Faculty Development Programs: Rapid Transition to ELearning during the Pandemic. Journal of Perinatal Medicine, 48(5), 446-49. https://doi.org/10.1515/ipm-2020-0197

Murphy, M.P.A. (2020). COVID-19 and Emergency ELearning: Consequences of the Securitization of Higher Education for Post-Pandemic Pedagogy. Contemporary Security Policy, 41(3), 492-505. https://doi.org/10.1080/13523260.2020.1761749 
Nunes-da-Cunha, I., \& Fernandez-Llimos, F. (2019). Teaching Pharmaceutical Care at University Level. In The Pharmacist Guide to Implementing Pharmaceutical Care, (eds. F. Alves da Costa, J. van Mil., A. Alvarez-Risco), Springer, Cham, pp.473-90. https://doi.org/10.1007/978-3-319-92576-9 39

Julius, E., Nuugulu, S., \& Julius, L.H. (2020). Estimating the Economic Impact of COVID-19: A Case Study of Namibia. Munich Personal RePEC Archive, https://mpra.ub.uni-muenchen.de/ id/eprint/99641

Nuwagira, E., \& Muzoora, C. (2020). Is Sub-Saharan Africa Prepared for COVID-19? Tropical Medicine and Health, 48(18). https://doi.org/10.1186/s41182-020-00206-x

Okereke, M., Adebisi, Y.A., Emmanuella, N., Jaber, H.M., Muthoni, L., \& Barka, N.B. (2020). COVID-19: Community Pharmacy Practice in Africa. International Journal of Health and Life Sciences, 6(2). https://doi.org/10.5812/ijhls.104517

Prince, T. (2016). "Panopto" for Lecture Capture - a First Time User's Perspective. International Journal of Innovation and Research in Educational Sciences, 3(5), 2349-5219. https://www. iiires.org/administrator/components/com_iresearch/files/publicat ions/IJIRES 680 FINAL.pdf

Rudall, N., Kalemeera, F., \& Rennie, T. (2015). Implementing Clinical Pharmacy within Undergraduate Teaching in Namibia. International journal of clinical pharmacy, 37(3), 427-29. https://doi.org/10.1007/s11096-015-0082-7

Safari, Y., Alikhani, A., \& Safari, A. (2016). Comparison of Blended and E-Learning Approaches in Terms of Acceptability in-Service Training Health Care Workers of Kermanshah University of Medical Sciences. International Journal of Pharmacy and Technology, 8(2), 12893-902.

Tesch, R. (2013). Qualitative Research: Analysis Types and Software Tools Qualitative Research: Analysis Types and Software Tools. Routledge, London. https://doi.org/10.4324/9780203989364

Tran, V.V., Lichtsteiner, S., Ernst, B., Otto, M., \& Folkers, G. (2003). Towards a Virtual Education in Pharmaceutical Sciences. An Innovative E-Learning Approach. In Current problems in dermatology, (ed. G. Burg), Basel, Karger, 32, pp.43-51. https://doi.org/10.1159/000067345

Vovides, Y., Chale, S.B., Gadhula, R., et al. (2014). A Systems Approach to Implementation of Elearning in Medical Education: Five MEPI Schools' Journeys. Academic Medicine, 89(8), pS102-S106. https://doi.org/10.1097/ACM.0000000000000347

Wicaksana, E. (2020). Efektifitas Pembelajaran Menggunakan Moodle Terhadap Motivasi Dan Minat Bakat Peserta Didik Di Tengah Pandemi Covid-19. EduTeach: Jurnal Edukasi dan Teknologi Pembelajaran, 1(2), 117-24. https://doi.org/10.37859/ eduteach.v1i2.1937 